today, no profession whose interests are better subserved by thorough preparation, long experience and natural aptitude than that of the librarian. A frequent change, therefore, together with the appointment of persons untrained and unacquainted with the requirements of the office is a policy greatly to be deplored. The libraries established by the state should be, unquestionably, bureaus of information, model libraries in the modern acceptation of the term.

\title{
THE OLD BLOCKHOUSE IN COUNCIL BLUFFS.
}

\author{
BY HON. D. C. BLOOMER.
}

This was the first building erected in Pottawattamie county. In 1838 the Pottawattamie Indians were removed by the United States, from the "Platte Purchase," so called, in Missouri, to a location on the Missouri river, which subsequently was organized into a county, and took the name of the tribe. Davis Hardin was their agent and came with them to their new home, the whole party, Indians and whites, numbered something less than three thousand. Mr. Hardin settled and cultivated a farm at Council Point, situated tive or six miles south of the present city of Council Bluffs. The Indians scattered over the broad valley and adjacent prairies and bluffs, and Mr. Hardin caused a mill to be built on Mosquito Creek, for grinding grain raised by them and himse'f.

In 1839 the general government stationed two companies of regular troops among these Indians for the purpose of keeping peace and quiet among them, although, 
through the careful management of the Agent, their presence did not prove necessary for that purpose. These troops located themselves a short distance up in the bluffs, in the little subsidiary valley of Indian creek and near a living spring found at that point. Here, on a gentle eleva-

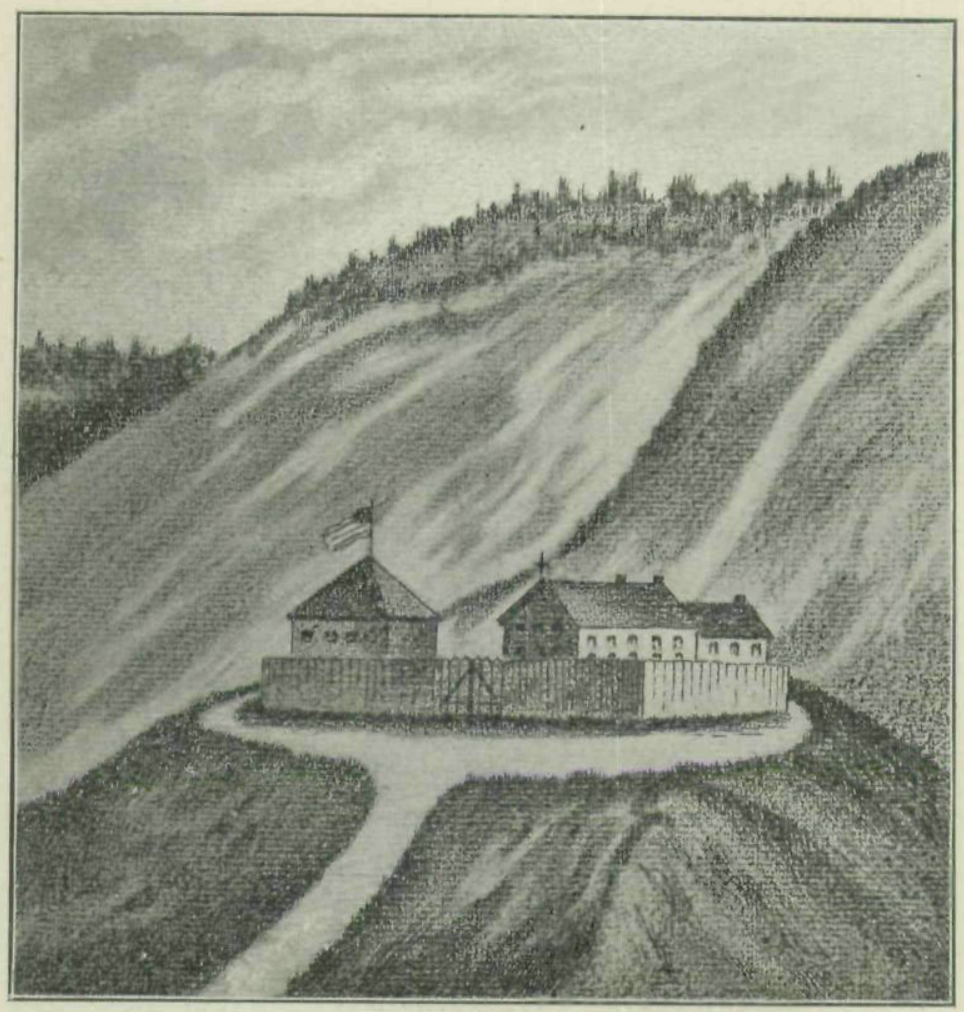

OLD BLOCKHOUSE AND BARRACKS, COUNCIL BLUFFS.

tion, in the same year they erected a blockhouse of logs and rough puncheons and raised the American Flag over it. Its sides were pierced with numerous holes through which muskets could be discharged in case of assault from without. The barracks, tents and parade grounds, and probably some minor structures, were located in the vicinity of this build- 
ing. No record can be found of the names of the officers in command of these troops. They did not remain a great while, for the reason already stated. With the Indians came a Roman Catholic mission in charge of two priests, Fathers De Smet and Verreydt. They also built for themselves a rude dwelling, but when the troops left took possession of the government buildings, blockhouse and barracks, for religious purposes, erecting a wooden cross over one of them. When the writer took up his residence in Council Bluffs in 1855, these buildings, (as shown in the cut), one of them surmounted by the cross, were yet standing, but used merely for storage purposes. They were demolished many years ago and the spot where they stood, is now occupied by the pleasant brick residence of $\mathrm{Mr}$. John Clausen. The place for the burial of the dead was situated just south of it, and on digging down the bluff for the fine Pierce Street School building now standing on the same spot, many human remains were unearthed. The Indians only remained in western Iowa eight or ten years, perhaps hardly as long, when they were removed to Kansas, where the remnant of the tribe still remains, and with them went also the members of the Catholic mission. They were succeeded by the Mormons, who came here from Nauvoo in 1846, and took possession of all this region for nearly a hundred miles up and down the Missouri river. In some histories of the county and city it has been stated that a Methodist minister named Rector in 1848 was the first to hold religious services, other than those held by the Mormons, in all this region. This is probably true so far as it relates to Protestant services, but it should be remembered that the Catholic priests I have mentioned, preached to the Indians, celebrated mass and performed other Christian rites at a much earlier day in the old buildings I have described.

It has recently been stated in an article printed in a eity paper, that this block house and a military post 
called Fort Atkinson, established by the United States Government on the Missouri River in 1820, were identical. But that certainly is a mistake. That fort was probably situated on the west side of the river and most likely about twenty miles above the city of Omaha, at a place known in later days as Fort Calhoun. Certainly, a military force was once stationed there, and it happens to be just at the place designated on the old maps of the western country as Council Point, having derived its name from a council supposed to have been held at that point with the Indians, by Lewis and Clark, while on their famous expedition up the Missouri river in the year 1803. We have the full report of that famous council in our libraries, but it is so worded that it is impossible to fix the locality with any certainty. It may have been held on the east side of the river, but more likely on the west side, and at some point 30 or 40 miles above the mouth of the Platte river. The explorers were evidently on both sides of the river. How came the name to be transferred from the west to the east side? The explanation is easy. When the old Mormon town of Kanesville was incorporated in 1853 by the General Assembly,* it was given, at the requesi of the residents, the name of Council Bluffs. It has proven a fortunate selection, for it has given to the city a world-wide celebrity; but in the midst of all its beauty and prosperity, its people should never forget that the blockhouse which once stood near the Bryant Spring, was certainly the first building, other than an Indian hut, erected within its limits.

Council Bluffs, Iowa, August, 1896. Iowa.

* Chapter 43, Laws of the Fourth General Assembly of the State of

Economy.-The last balloon sleeve was eut up the other day at this place; it made two dresses for a little girl, one apron, six capes, and a dozen night-caps. :Iowa News, Dubuque, June 17, 1837. 
Copyright of Annals of Iowa is the property of State of Iowa, by \& through the State Historical Society of Iowa and its content may not be copied or emailed to multiple sites or posted to a listserv without the copyright holder's express written permission. However, users may print, download, or email articles for individual use. 